\title{
Lifestyles and social participation
}

\section{Carla Seddon}

Edition No: Social Trends 41

Editor: Jen Beaumont

Office for National Statistics

\section{Social Trends 41}


ISSN 2040-1620

\section{A National Statistics publication}

National Statistics are produced to high professional standards set out in the Code of Practice for Official Statistics. They are produced free from political influence.

Not all of the statistics contained in this publication are National Statistics because it is a compilation from various data sources.

\section{About us}

\section{The Office for National Statistics}

The Office for National Statistics (ONS) is the executive office of the UK Statistics Authority, a non-ministerial department which reports directly to Parliament. ONS is the UK government's single largest statistical producer. It compiles information about the UK's society and economy, and provides the evidence-base for policy and decision-making, the allocation of resources, and public accountability. The DirectorGeneral of ONS reports directly to the National Statistician who is the Authority's Chief Executive and the Head of the Government Statistical Service.

\section{The Government Statistical Service}

The Government Statistical Service (GSS) is a network of professional statisticians and their staff operating both within the Office for National Statistics and across more than 30 other government departments and agencies.

\section{Contacts}

\section{This publication}

For information about the content of this publication, contact Jen Beaumont

Tel: 01633651622

Email: social.trends@ons.gsi.gov.uk

\section{Other customer enquiries}

ONS Customer Contact Centre

Tel: 08456013034

International: +44(0)8456013034

Minicom: 01633815044

Email: info@statistics.gsi.gov.uk

Fax: 01633652747

Post: Room 1.101, Government Buildings,

Cardiff Road, Newport, South Wales NP10 8XG

www.ons.gov.uk

\section{Media enquiries}

Tel: 08456041858

Email: press.office@ons.gsi.gov.uk

\section{Copyright and reproduction}

(C) Crown copyright 2011

You may re-use this information (not including logos) free of charge in any format or medium, under the terms of the Open Government Licence.

To view this licence, go to: www.nationalarchives.gov.uk/doc/open-governmentlicence/

or write to the Information Policy Team, The National Archives, Kew, London TW9 4DU

email: psi@nationalarchives.gsi.gov.uk

Any enquiries regarding this publication should be sent to: info@statistics.gsi.gov.uk

This publication is available for download at: www.ons.gov.uk 
Lifestyle is defined as a way of living: the things that a particular person or group of people usually do. Lifestyles are based on individual choices, characteristics, personal preferences and circumstances. In their free leisure time many choose to engage in the arts and culture, read a book, visit the cinema, go on holiday and participate in sporting activities. Social participation includes looking after the family or home and care giving; interpersonal roles of friend and family member; life roles such as student, worker and volunteer; and community roles such as participant in religious, activity based, or voluntary help organisations.

\section{Key points:}

\section{Leisure and entertainment activities}

- In 2009/10, almost 9 in 10 (89 per cent) of adults aged 16 and over in England watched television in their spare time

- $\quad$ In 2009/10, adults in the UK aged 16 and over spent an average of 3 and a half hours a day watching television, 2 and a half hours using a computer and 1 hour listening to radio

- $\quad$ In 2009, UK teenagers and young adults aged 15 to 24 were the most frequent cinema goers, with 61 million cinema admissions

- $\quad$ In 2009, almost all (98.0 per cent) of single music tracks were purchased digitally, with digital sales increasing by 91.9 per cent between 2007 and 2009

- $\quad$ Sales of books by UK publishers fell by 5.9 per cent from 492 million books in 2007 to 463 million in 2009

- Between 2005/06 and 2009/10 the proportion of adults aged 16 and over visiting a public library in England fell from 48 per cent to 39 per cent

- In 2009, 22 per cent of children aged 8 to 16 stated they enjoy reading very much compared to 10 per cent who do not enjoy reading at all

- $\quad$ In 2010, less than half of adults in Great Britain aged 15 and over read a national daily newspaper (41 per cent): on average since 1981 the proportion reading national newspapers has fallen by approximately 10 percentage points every 10 years

\section{Holidays and day trips}

- Holiday visits abroad decreased by 15 per cent from 45.5 million visits in 2008 to 38.5 million visits in 2009, the lowest levels since 2000

- In 2009 Spain remained the most popular destination for UK residents going abroad on holiday (26 per cent of holiday visits), the Irish Republic was the most common destination for UK residents travelling abroad to visit friends and relatives (14 per cent of visits)

- UK residents aged 45 to 54 took the most holiday visits abroad in 2009, with 7.6 million visits

- In 2008/09 around 563,000 households in England had a second home, amounting to 651,000 properties, 58 per cent of which were located outside the UK

- $\quad$ Domestic holiday tourism grew by 12 per cent from 75 million trips within the UK in 2008 to 84 million in 2009 
- $\quad$ The most popular type of heritage site visited by adults aged 16 and over in England in 2009/10 was an historical city or town, with 55 per cent of adults visiting these

\section{Sporting activities}

- $\quad$ The proportion of adults aged 16 and over in England who participate in active sport for at least 30 minutes in the last four weeks decreases with age: 75 per cent of those aged 16 to 24 compared with 18 per cent of those aged over 75 (figures for 2009/10)

- In 2009, 40 per cent of UK adults who did not practice sport said that lack of time was the main reason

- $\quad$ Over half (55 per cent) of children in school years 1 to 13 in England participated in at least 3 hours of high quality Physical Education (PE) and out of hours sport in a typical week in 2009/10

\section{Social and political participation}

- $\quad$ A total of 29.7 million valid votes were cast in the 2010 UK general election, a turnout rate of 65.1 per cent, higher than in the previous two general elections

- In England in 2009/10, 29 per cent of adults aged 16 and over volunteered informally at least once a month and 54 per cent at least once a year, compared with 35 per cent and 62 per cent in 2008/09

- In 2009/10, 34 per cent of adults aged 16 and over in England had engaged in some sort of civic participation, a decrease from 38 per cent in 2001

- $\quad$ The estimated total amount donated to charity in 2009/10 was £10.6 billion, up 3.9 per cent compared with 2008/09 when $£ 10.2$ billion was donated. However donations have not returned to the pre recession record level of $£ 11.3$ billion recorded in 2007/08

\section{Religion}

- In 2008/09, 32 per cent of adults aged 16 and over in England and Wales who reported being Christian actively practiced their religion, compared with 80 per cent of those who reported being Muslim

- In 2008/09, 30 per cent of adults aged 16 and over in England and Wales who practiced their religion stated that this influenced the school to which they sent or would send their child 


\section{Leisure and entertainment activities}

Leisure, or free time, is a period of recreational time spent on non-compulsory activities when individuals can choose to spend their time doing the things they enjoy.

People spend this time taking part in a wide range and variety of activities, depending on individual preferences and lifestyles.

\begin{tabular}{|c|c|c|c|c|c|c|}
\hline \multirow[t]{2}{*}{ England } & & & & & \multicolumn{2}{|c|}{ Percentages } \\
\hline & $16-24$ & 25-34 & 35-44 & 45-64 & $\begin{array}{r}65 \text { and } \\
\text { over }\end{array}$ & $\begin{array}{r}\text { All aged } 16 \\
\text { and over }\end{array}$ \\
\hline Watching television & 88 & 85 & 88 & 89 & 92 & 89 \\
\hline Spending time with friends/family & 87 & 85 & 85 & 83 & 82 & 84 \\
\hline Listening to music & 90 & 78 & 76 & 74 & 69 & 76 \\
\hline Shopping & 71 & 73 & 74 & 69 & 69 & 71 \\
\hline Reading & 53 & 62 & 65 & 72 & 73 & 67 \\
\hline Eating out at restaurants & 66 & 71 & 70 & 72 & 65 & 69 \\
\hline Days out & 54 & 65 & 68 & 67 & 59 & 63 \\
\hline Internet/emailing & 79 & 77 & 71 & 57 & 24 & 59 \\
\hline Sport/exercise & 63 & 63 & 60 & 55 & 35 & 54 \\
\hline Gardening & 16 & 36 & 51 & 64 & 62 & 49 \\
\hline Going to pubs/bars/clubs & 59 & 63 & 50 & 44 & 33 & 48 \\
\hline Going to the cinema & 72 & 61 & 55 & 42 & 21 & 48 \\
\hline
\end{tabular}

1 Respondents were shown a list of activities and asked to pick the things they did in their free time in the last year prior to interview. The most popular activities performed by all adults aged 16 and over are shown in the table.

Source: Taking Part: The National Survey of Culture, Leisure and Sport, Department for Culture, Media and Sport (2010)

Watching television has been a common pastime for decades and continues to be so in 2009/10. The latest data from the Taking Part Survey' show that watching television in their free time was still the most common activity reported by adults aged 16 and over in England (Table 1). Eighty nine per cent of all adults watched television in their free time and it was the most popular activity for age groups from 35 upwards. However, for those aged 16 to 24 spending time listening to music was selected by the highest proportion of respondents (90 per cent). Those aged 25 to 34 reported spending time with friends and family as their joint top activity along with watching television, with 85 per cent of respondents in this age group saying that they did these activities in their free time.

Overall, for adults aged 16 and over, spending time with family and friends was the second most popular activity at 84 per cent, listening to music came next at 76 per cent and shopping was fourth at 71 per cent. 
The overall averages also hide differences between the age groups for other activities. Comparing the 16 to 24 age group with those aged 65 and over, the activities which were reported less frequently as age increased were listening to music ( 90 per cent and 69 per cent respectively); Internet and emailing (79 per cent and 24 per cent); sport and exercise (63 per cent and 35 per cent); going out to pubs, clubs or bars (59 per cent and 33 per cent); and going out to the cinema (72 per cent and 21 per cent). Again comparing the youngest and oldest age groups, the activities which were reported more frequently as age increased were reading (53 per cent and 73 per cent) and gardening (16 per cent and 62 per cent).

\section{Figure $1 \quad$ Minutes per day spent using each medium: by age, 2009/10} United Kingdom

Hours and minutes per day

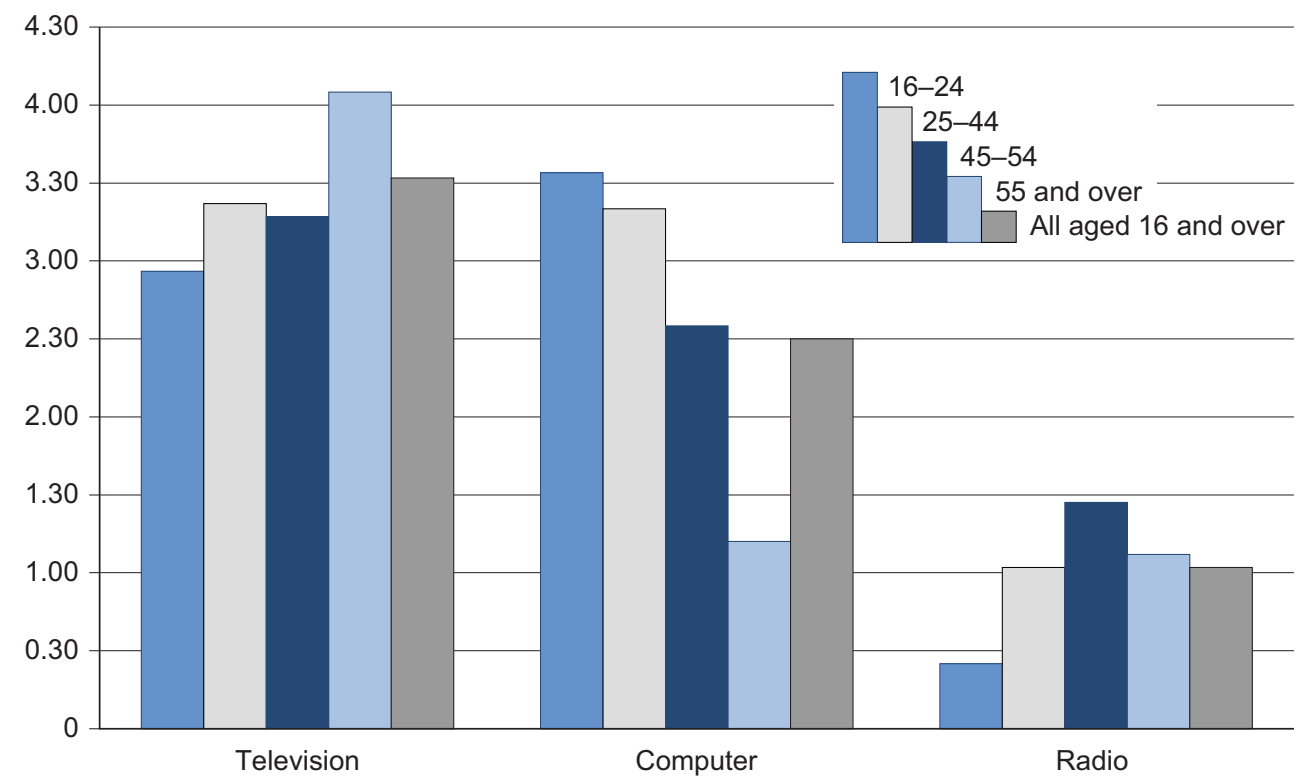

Source: Ofcom (2010)

Estimates from Ofcom show that on average in 2009/10, adults aged 16 and over in the UK spent 3 hours and 32 minutes a day watching television, 2 and a half hours using a computer per day and 1 hour and 2 minutes a day listening to a radio (Figure 1). Those aged 55 and over, spent the most time a day watching television at 4 hours and 5 minutes a day, while those aged 16 to 24 spent the least at an average of 2 hours and 56 minutes a day.

Radio listening was highest among those aged 45 to 54 at 1 hour 27 minutes and, as was the case with time spent watching television, people aged 16 to 24 spent the least time listening to the radio at 25 minutes a day.

Conversely, people aged 16 to 24 spent the highest amount of time using a computer, an average of 3 hours and 34 minutes a day. The amount of time spent using a computer decreased with age, with those aged 25 to 44 spending 3 hours and 20 minutes a day doing so, falling to 2 hours and 35 minutes a day for those aged 45 to 54 and to 1 hour and 12 minutes a day for those aged 55 and over. 
As shown in Table 3 of the Social Trends 41 e-society chapterii, released in November 2010, Ofcom research also shows that watching television is the media activity adults claim they would miss the most if they were deprived of it. In 2009 half of adults in the UK aged 16 and over (50 per cent) cited television as their most-missed medium, although this varied with age. Among younger adults (16 to 24 -year-olds) the figure drops to 36 per cent, compared with 57 per cent among adults aged 55 to 64 (Ofcom, 2010).

Going to the cinema to watch the latest film releases remains a common pastime for many. According to the UK Film Council, cinema-going was not affected by the recession. There were 174 million cinema visits in the UK in 2009 , an increase of 5.6 per cent compared with 2008 , while box office receipts grew to a record £944 million. The number of admissions in 2009 was the highest since 2002 when admissions reached 176 million. However, cinema admissions were at their highest in 1946 when there were 1.6 billion ticket sales (UK Film Council, 2010).

Figure 2

Annual cinema admissions: by age

United Kingdom

Millions

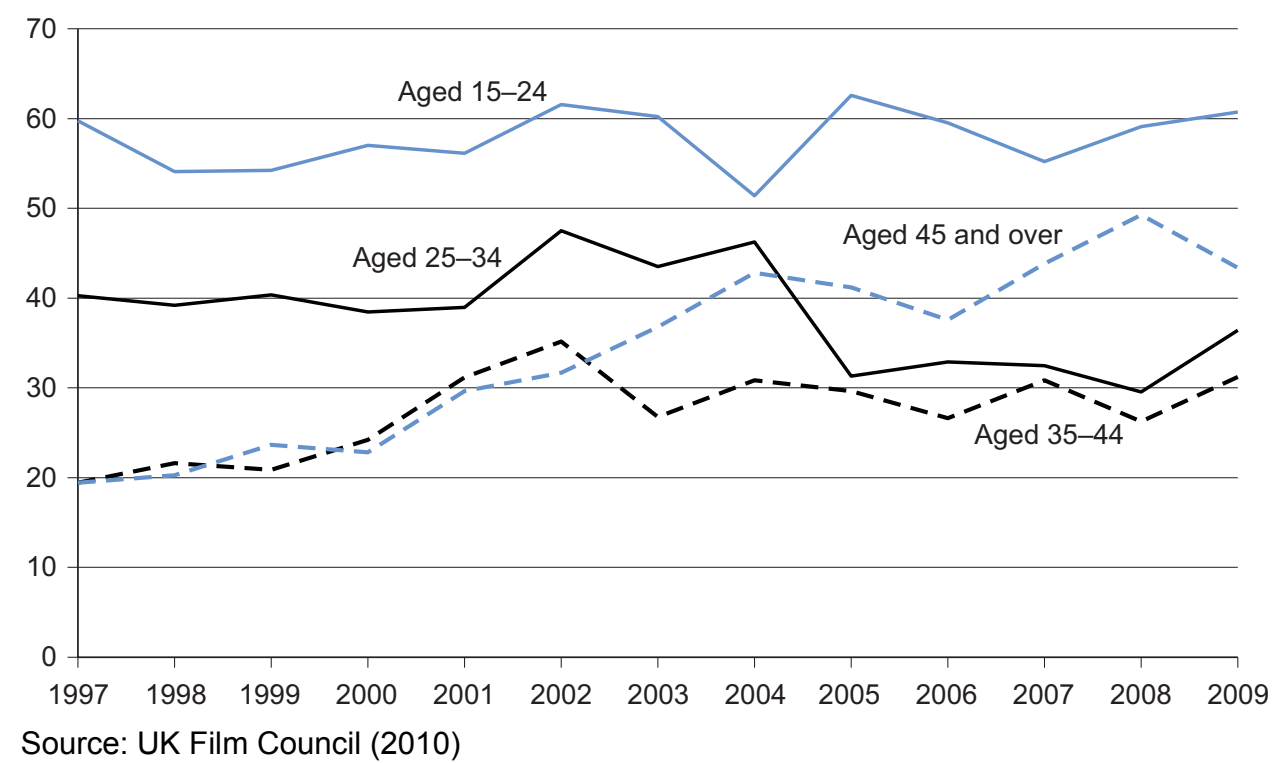

As in previous years, teenagers and young adults in the UK aged 15 to 24 were the most frequent cinema-goers in 2009, accounting for 61 million cinema admissions (Figure 2). The number of admissions for people aged 45 and over gradually increased from 19 million in 1997 to 49 million in 2008, while those aged 25 to 34 fell from 40 million admissions to 30 million over the same period.

Between 2008 and 2009 changes in cinema admissions differed by age: while there were increases in the 15 to 24,25 to 34 and 35 to 44 age groups, there was a decrease of 12 per cent for people aged 45 and over. However, the over 45 s are still the second largest group of cinemagoers, after overtaking people aged 25 to 34 in 2005. In 2009 people aged 45 and over accounted for 43 million admissions, followed by those aged 25 to 34 at 36 million admissions and those aged 35 to 44 at 31 million admissions. 
A survey of cinema-goers' opinions, conducted by YouGov in 2010, found that half of cinemagoers (50 per cent) who had visited the cinema in the previous 6 months thought that the cinema had become too expensive. However, 61 per cent of cinema-goers also agreed that 'you can't beat watching a film on the big screen'. Additionally, 27 per cent agreed that films are a 'great way to escape from the modern world', while 19 per cent agreed that 'the cinema was too noisy when they preferred it to be quiet' and 14 per cent thought that there was 'not enough choice these days at the cinema' (YouGov, 2010a).

According to the Entertainment Retailers Association (ERA), sales in the recorded music sector in the UK in 2009 were only slightly affected by the recession. Unit sales were down just 0.5 per cent and the value of sales was down only 0.8 per cent from 2008 (Entertainment Retailers Association, 2010).

\section{Figure $3 \quad$ Retail sales of music (singles and albums units sold)}

United Kingdom

Millions

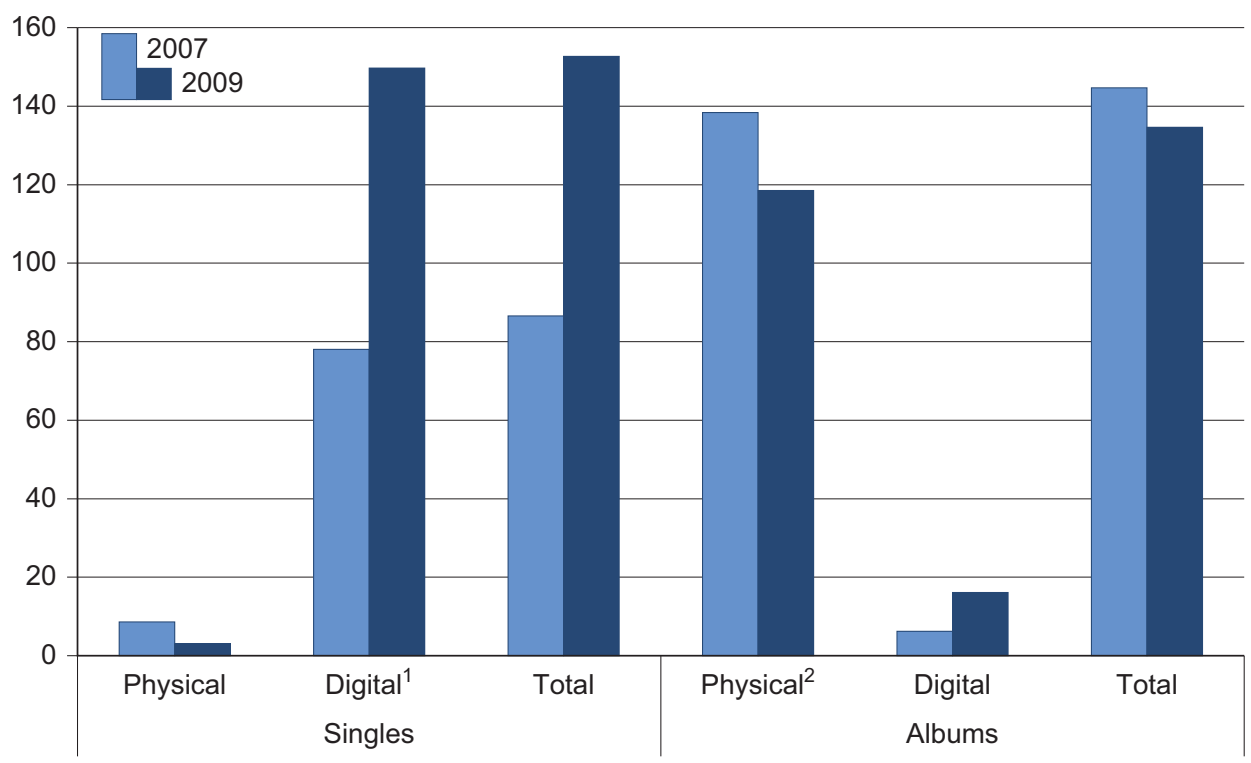

1 Combines single track and album sales.

2 Up-weighted from Official Charts Company data to reflect 100 per cent of the market.

Source Official Charts Company (ERA, 2010)

Estimates from the Official Charts Company (OCC) shows that almost all single music tracks (98.0 per cent) were purchased digitally instead of in physical formats in the UK in 2009 and digital sales increased by 91.9 per cent between 2007 and 2009. Overall volume of sales of singles have grown. In 2007 consumers purchased a combined 87 million physical and digital singles. This increased by 76.3 per cent in 2009 to 153 million (Figure 3). In part, this increase could be attributed to the increased availability of tracks to download as singles on music download services such as iTunes, where people can easily purchase individual tracks rather than whole albums. This could also be one of the reasons for the decrease of 7.0 per cent in the number of albums sold, from 145 million units in 2007 to 135 million units in 2009 (Entertainment Retailers Association, 2010). 
While sales of albums in digital format increased by 160 per cent between 2007 and 2009, digital sales of albums are still much lower than for digital singles, accounting for 12 per cent of all album sales, with 16 million digital units sold in 2009 compared with 119 million physical units sold. The sales of albums in physical format fell between 2007 and 2009, dropping 14 per cent from 138 million units in 2007 to 119 million in 2009 (Entertainment Retailers Association, 2010).

The value of the UK book market in 2009 at end-purchaser prices was estimated at $£ 3.4$ billion according to The Publishers Association. This represented a decrease of 2.9 per cent from 2008, when the value was $£ 3.5$ billion, but an increase of 3.8 per cent from $£ 3.3$ billion in 2005 (Publishers Association, 2009).

\section{Figure $4 \quad$ UK sales by UK publishers (units sold): by category}

United Kingdom

Millions

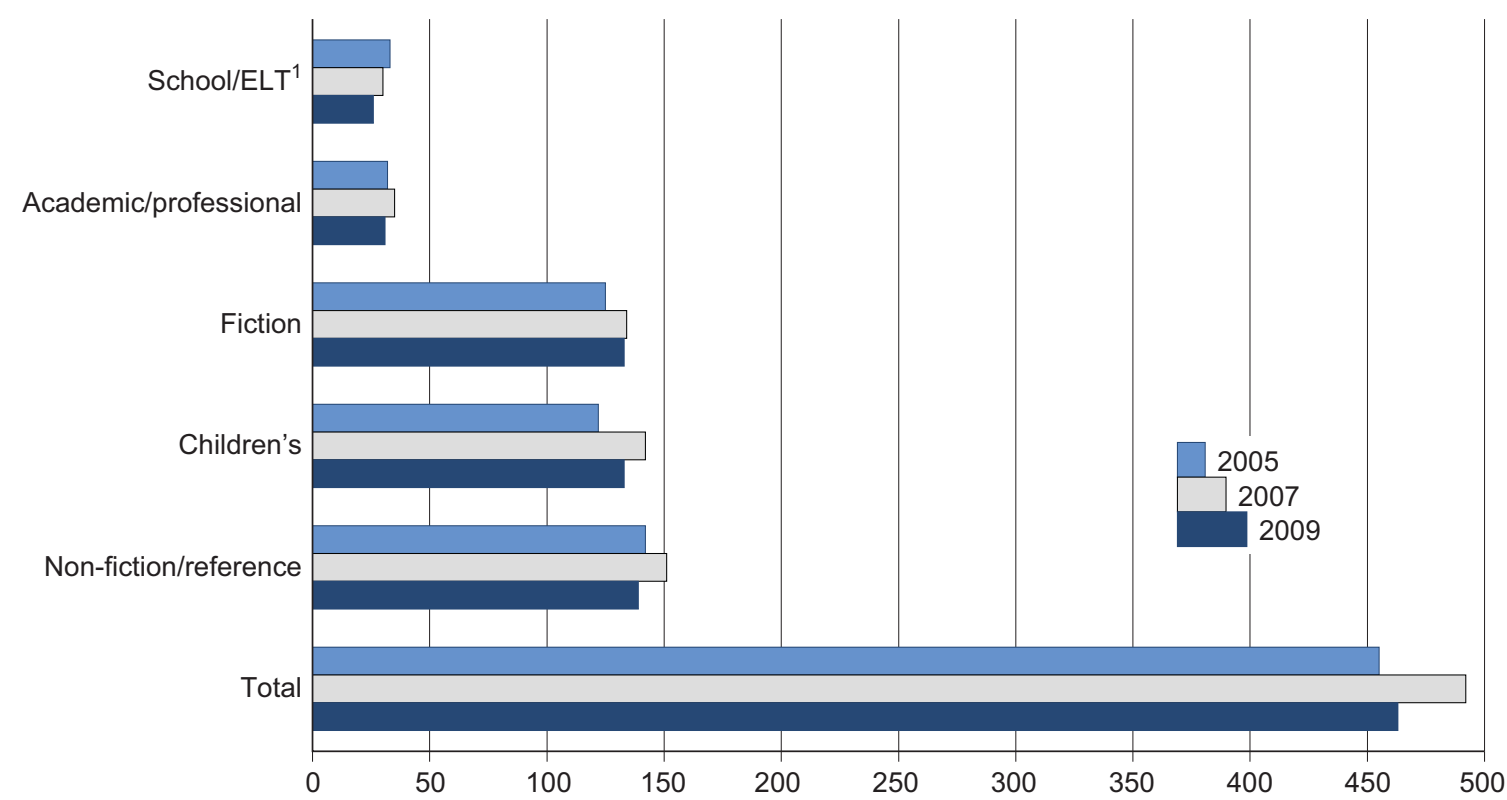

1 English language teaching.

Source: The Publishers Association (2009)

Overall in 2009 there were decreases in UK publishers' net book unit sales to the UK market in each of the five main categories when compared with 2007, while between 2005 and 2007 total unit sales increased (Figure 4). However, although there was a 5.9 per cent drop in unit sales to 463 million in 2009 from 492 million in 2007, sales in 2009 remained 1.8 per cent higher than the 455 million units sold in 2005.

Between 2005 and 2009, the overall growth in book sales was driven by increases in children's and fiction books: 9.5 per cent and 6.3 per cent respectively. During the same period, sales in all other categories decreased, with school/English language teaching (ELT) showing the largest decrease at 22.7 per cent.

Other data from the Publishers Association show that the total revenue from UK publishers' sales of digital products is rising, reaching just over $£ 150$ million in 2009. This could be split 
approximately by $£ 5$ million digital sales to the general consumer, $£ 8$ million sales for consumer reference, £8-9 million sales for school/ELT and $£ 130$ million sales for academic/professional. Overall, digital sales represent around 4 to 5 per cent of the combined physical and digital sales of UK publishers in 2009 (Publishers Association, 2009).

Reading is a common pastime, with many choosing to borrow books from libraries as an alterative to purchasing personal copies. According to data from Public Lending Right (PLR) in 2008/09, fiction remained the most common genre of borrowed books from UK libraries, accounting for 44.3 per cent of loans. The next most common genre was children's and educational books at 34.8 per cent, followed by family, home and practical interests at 5.3 per cent (Public Lending Right, 2009).

Overall the number of books issued by public libraries in England has fallen from 279 million in $2004 / 05$ to 264 million in 2008/09. The number of adult fiction books issued decreased from 135 million to 122 million over the same period. Adult non-fiction issues fell from 68 million to 60 million and child non-fiction from 12 million to 11 million. However, child fiction books issued increased in number from 63 million books in 2004/05 to 69 million in 2008/09 (Museums, Libraries \& Archives, 2010a).

There were 10 million active borrowers (those that visit the library for the purpose of borrowing books) from public libraries in England in 2008/09, a decline of 10 per cent from 11 million borrowers in 2004/05. However the number of books issued each year per active borrower increased over the same period from 24 books per active borrower in 2004/05 to 26 books in 2008/09 (Museums, Libraries \& Archives, 2010a).

\section{Figure $5 \quad$ Proportion of adults ${ }^{1}$ who have visited a public library in the last year}

England

Percentages

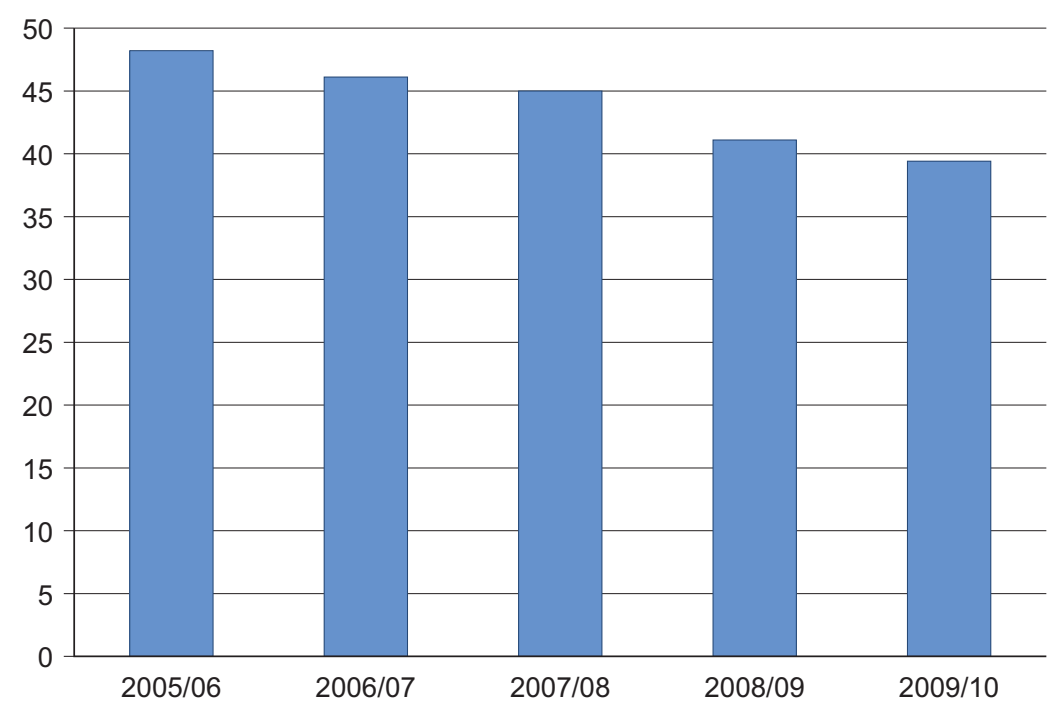

1 Adults aged 16 and over.

Source: Taking Part: The National Survey of Culture, Leisure and Sport, Department for Culture, Media and Sport (2010)

The Taking Part Survey shows that between 2005/06 and 2009/10 there was a steady decrease in the proportion of adults aged 16 and over visiting a public library in England, from 48 per cent to 39 
per cent (Figure 5). The largest year-on-year decrease was between 2007/08 and 2008/09 with a fall of 3.9 percentage points.

In 2009/10, women were more likely than men to have visited a public library in the last 12 months, 43 per cent having done so compared with 36 per cent of men. Looking at the frequency with which adults visit the library, 5.4 per cent visited a public library at least once a week; 12.8 per cent visited at least once a month; 10.9 per cent visited 3 to 4 times a year and 7.9 per cent visited 1 to 2 times a year (Department for Culture, Media and Sport, 2010).

The Taking Part Survey also reported that in 2009/10, 93.8 per cent of those people who had visited a public library had done so in their own time while 10.3 per cent visited for the purpose of academic study and 3.1 per cent for paid work (Department for Culture, Media and Sport, 2010).

\section{Figure 6 Children's ${ }^{1}$ attitude towards reading, 2009}

\section{United Kingdom}

Percentages

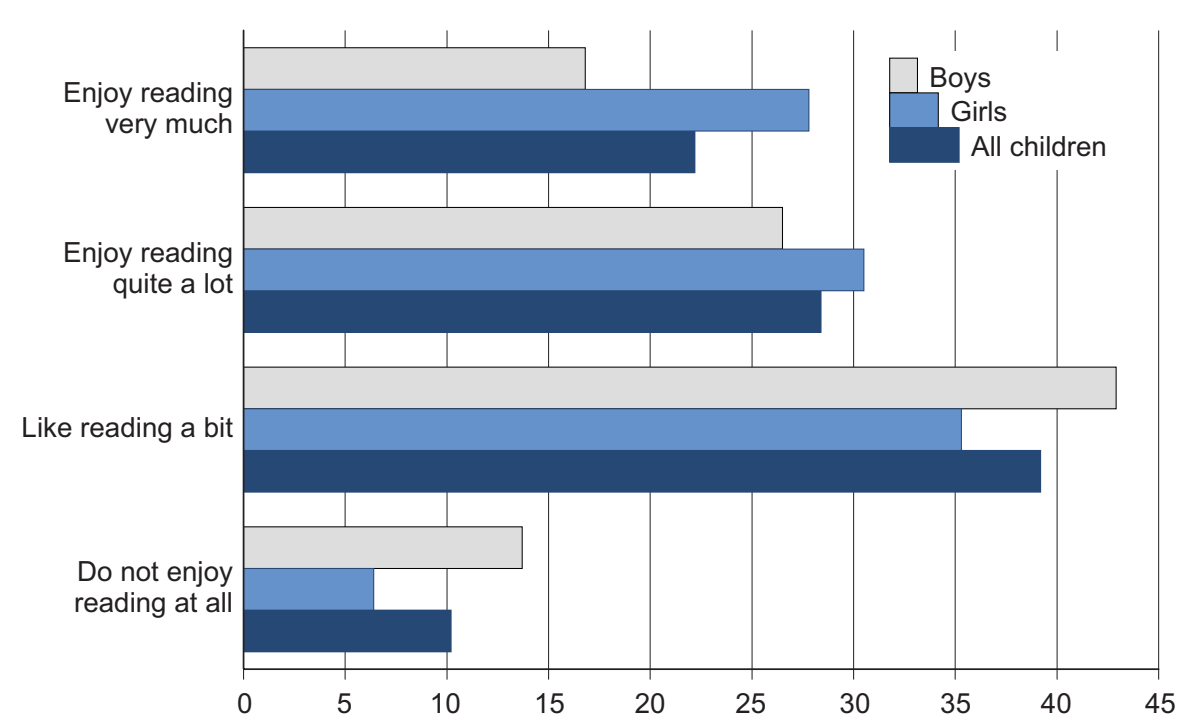

1 Children aged 8 to 16 .

Source: The National Literacy Trust (forthcoming publication)

Research from the National Literacy Trust found that the majority of children get some amount of enjoyment out of reading. Figure 6 shows that among children aged 8 to 16, 22 per cent stated that they enjoy reading very much, while 28 per cent said they enjoy reading quite a lot. However the most frequent response was that they like reading a bit (39 per cent) while 10 per cent stated that they did not enjoy reading at all.

Overall, girls enjoyed reading more than boys, with 28 per cent of girls compared with 17 per cent of boys saying that they enjoy reading very much and 31 per cent of girls and 27 percent of boys stating the enjoy reading quite a lot.

Since the literacy trust first conducted this survey in 2005, levels of enjoyment of reading have remained unchanged. However, the gap in reading enjoyment between boys and girls appears to 
have widened, increasing from a percentage point difference of 11 per cent in 2005 to a 15 per cent point difference in 2009 (National Literacy Trust, forthcoming publication).

\section{Table $2 \quad$ Readership of national daily newspapers ${ }^{1}$}

\begin{tabular}{|c|c|c|c|c|c|}
\hline \multirow[t]{2}{*}{ Great Britain } & \multirow[b]{2}{*}{1971} & \multirow[b]{2}{*}{1981} & \multirow[b]{2}{*}{1991} & \multicolumn{2}{|c|}{ Percentages } \\
\hline & & & & 2001 & 2010 \\
\hline The Sun & 17 & 26 & 22 & 20 & 16 \\
\hline Daily Mail & 12 & 12 & 10 & 12 & 10 \\
\hline Daily Mirror & 34 & 25 & 22 & 12 & 7 \\
\hline The Daily Telegraph & 9 & 8 & 6 & 5 & 4 \\
\hline The Times & 3 & 2 & 2 & 3 & 3 \\
\hline Daily Express & 24 & 14 & 8 & 4 & 3 \\
\hline Daily Star & - & 9 & 6 & 3 & 3 \\
\hline The Guardian & 3 & 3 & 3 & 2 & 2 \\
\hline The Independent & - & - & 2 & 1 & 1 \\
\hline Financial Times & 2 & 2 & 2 & 1 & 1 \\
\hline Any national daily newspaper ${ }^{2}$ & - & 72 & 62 & 53 & 41 \\
\hline
\end{tabular}

1 In the 12 months to June each year. Proportion of adults, aged 15 and over, who have read or looked at the individual newspaper for at least two minutes on the day before interview.

2 Includes the above newspapers and The Daily Record in 1981, and The Sporting Life and the Racing Post in 2001.

Source: National Readership Survey (2010)

The estimated proportion of adults aged 15 and over in Great Britain who read a national daily newspaper has been decreasing over the past 30 years, from 72 per cent of adults in 1981 to 41 per cent in 2010 according to the National Readership Survey (Table 2). On average since 1981 the proportion reading national newspapers has fallen by approximately 10 percentage points every 10 years.

The most commonly read newspaper in 2010 was The Sun, though readership has decreased from 26 per cent of adults who read newspapers in 1981 to 16 per cent in 2010. In fact, most tabloid newspapers experienced substantial falls in readership over this period. The Daily Mirror suffered the largest decrease, falling from being the most commonly read in 1971, when 34 per cent of adults read it, to 7 per cent in 2010. The Daily Express has also suffered a similar fate, falling from 24 per cent in 1971 to 3 per cent in 2010.

The readership of most other newspapers has also remained stable, fluctuating by only one or two percentage points over the period. These are mainly the broadsheets, which have kept their smaller but more targeted audiences. 
The decline in the proportion of those reading national newspapers may be affected by the availability of news websites which are free on the Internet. A recent survey by YouGov asked whether respondents would consider paying for access to online news sites. Only 2 per cent stated yes they definitely would, while a further 4 per cent said they would pay but only for special content, for instance content not available elsewhere. A further 6 per cent stated they might possibly pay for online content, while the majority (83 per cent) stated that they would not consider paying for access to newspapers online (YouGov, 2010b). 


\section{Holidays and day trips}

During extended periods of free time, many people choose to take holidays away from home to get away from their everyday lives. The choice of destination is based not only on the amount of money available to spend on a holiday but also on individual preferences, which may range from gaining new experiences, seeing new cultures, enjoying a different climate or spending time relaxing.

Holidays are such an important part of life for many that they spend all year saving up for their week or two away. However, according to the International Passenger Survey, in 2009 UK residents cut back substantially on the number of holidays taken abroad: holiday visits abroad decreased by 15 per cent from 45.5 million visits in 2008 to 38.5 million in 2009 . This was the lowest level since 2000 when 36.7 million holiday visits were taken (Office for National Statistics, 2010).

\section{Table 3 UK residents' holiday visits abroad: by destination ${ }^{1}$}

\begin{tabular}{lrrrrr} 
United Kingdom & & & \multicolumn{2}{c}{ Percentages $^{2}$} \\
\hline Spain & 1981 & 1991 & $\mathbf{2 0 0 1}$ & $\mathbf{2 0 0 8}$ & $\mathbf{2 0 0 9}$ \\
France & 22 & 21 & 28 & 27 & 26 \\
Italy & 27 & 26 & 18 & 17 & 18 \\
United States & 6 & 4 & 4 & 5 & 5 \\
Portugal & 5 & 7 & 6 & 5 & 5 \\
Greece & 3 & 5 & 4 & 5 & 4 \\
& 7 & 8 & 8 & 4 & 4 \\
Turkey & & & & & 4 \\
Ireland & - & 1 & 2 & 4 & 3 \\
Cyprus & 4 & 3 & 4 & 3 & 2 \\
Netherlands & 1 & 2 & 4 & 2 & 2 \\
Other countries & 2 & 4 & 3 & 2 & 25 \\
& 23 & 20 & 20 & 26 & 38.5 \\
All destinations (=100\%) (millions) & 13.1 & 20.8 & 38.7 & 45.5 & \\
\hline
\end{tabular}

1 As a proportion of all holidays taken abroad by residents of the UK. Excludes business trips and other miscellaneous visits.

2 Percentages may not add up to 100 per cent due to rounding.

Source: International Passenger Survey, Office for National Statistics (2010)

In 2009, 26 per cent of UK residents travelling abroad for their holiday went to Spain (Table 3).

France is also a popular destination, in second place in the top 10 destinations with 18 per cent of holiday visits. However, France has seen a decline in popularity over the years, falling from 27 per cent in 1981. 
Both Italy and the United States had 5 per cent of visits in 2009, followed by Portugal, Greece and Turkey with 4 per cent. Turkey has seen a rise in the share of visits for holiday purposes, increasing from 1 per cent in 1991 to 4 per cent in 2009. In contrast, the percentage of those visiting Greece for a holiday has fallen by half, from 8 per cent in 1991 to 4 per cent in 2009 .

Those taking trips abroad to visit friends and relatives also decreased in 2009: by 6.4 per cent from 12.4 million visits in 2008 to 11.6 million visits in 2009 (Office for National Statistics, 2010).

\section{Table $4 \quad$ UK residents' visits to friends and relatives ${ }^{1}$ abroad: by destination}

United Kingdom

\begin{tabular}{rrr} 
& \multicolumn{2}{c}{ Percentages $^{2}$} \\
\hline $\mathbf{2 0 0 3}$ & $\mathbf{2 0 0 6}$ & $\mathbf{2 0 0 9}$ \\
16 & 15 & 14 \\
1 & 11 & 11 \\
9 & 6 & 9 \\
6 & 9 & 8 \\
7 & 6 & 5 \\
\hline & 6 & 5
\end{tabular}

$\begin{array}{lrrrr}\text { India } & 3 & 3 & 3 & 4 \\ \text { Italy } & 3 & 4 & 4 & 3 \\ \text { Netherlands } & 5 & 4 & 3 & 3 \\ \text { Pakistan } & 2 & 3 & 3 \\ \text { Other countries } & 34 & 34 & 35\end{array}$

All destinations $(=100 \%)$ (millions)

6.6

8.5

12.0

11.6

1 As a proportion of all visits to friends and relatives taken abroad by residents of the UK. Excludes business trips and other miscellaneous visits.

2 Percentages may not add up to 100 per cent due to rounding.

Source: International Passenger Survey, Office for National Statistics (2010)

For visits for this purpose the Irish Republic remained the most common destination throughout the period shown in the table, accounting for 14 per cent of such trips in 2009 (Table 4). However, although the Irish Republic remained top of the list for visits, there has been a steady decrease in the proportion of visits made there to visit friends and relatives from 19 per cent in 1999. The second most common country visited to see friends and relatives was France with 11 per cent of visits, followed by Poland with 9 per cent. Poland has seen the largest rise of the top 10 destinations, increasing from 1 per cent of all visits in 1999. This reflects the change in international migration patterns following Poland's accession to the European Union in May 2004. 


\section{Figure 7 Holiday visits abroad by UK residents: by age ${ }^{1}$}

United Kingdom

Millions

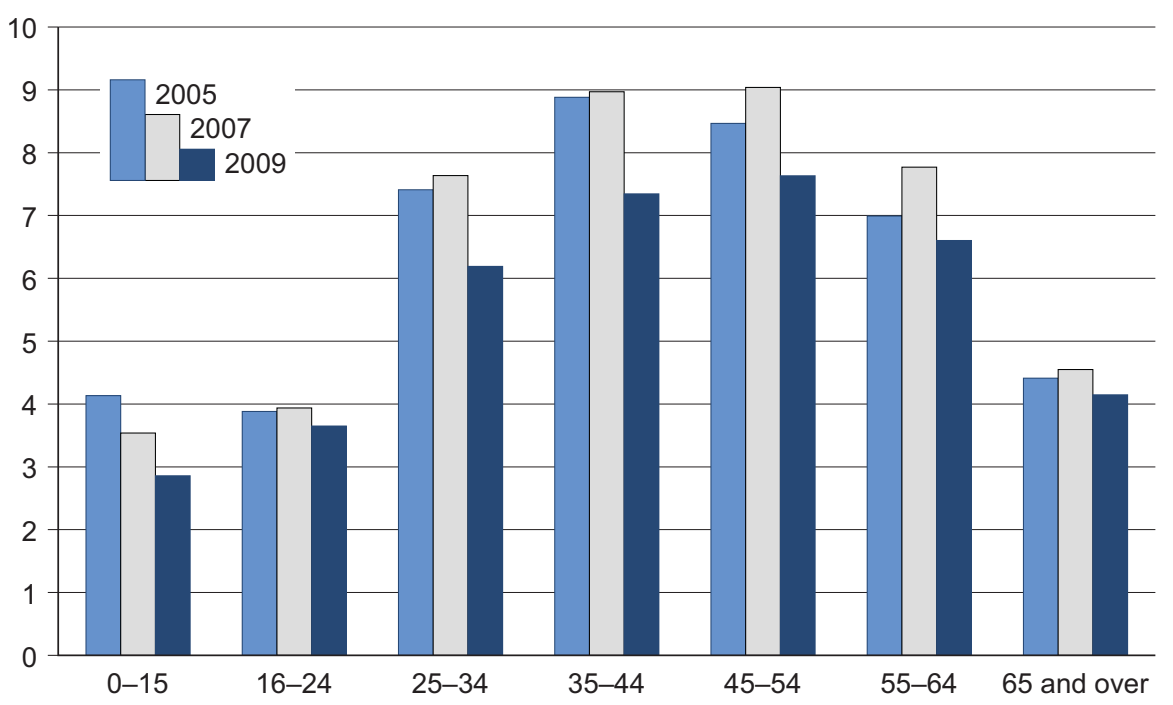

1 Does not include visits for UK residents whose age was unknown.

Source: International Passenger Survey, Office for National Statistics (2010)

In 2009 people aged 45 to 54 took the most holidays abroad ( 7.6 million visits or 19.9 per cent of all holidays visits abroad), people aged between 35 and 44 made 7.3 million visits (19.1 per cent) and those aged 55 to 64 made 6.6 million visits (17.2 per cent) (Figure 7).

In comparison, people aged 65 and over took 4.1 million visits abroad (10.8 per cent), young adults, aged 16 to 24 made 3.6 million visits, accounting for 9.5 per cent of visits, and those aged 0 to 15 years went on 2.9 million holiday visits abroad ( 7.4 per cent).

The number of holiday visits abroad in all age groups was lower in 2009 than 2005. The largest percentage decreases in visits between 2005 and 2009 were by those aged 0 to 15 (31 per cent) and people aged 35 to 44 (17 per cent). 
The English Housing Surveyiii estimates that around 563,000 households in England in 2008/09 had one or more second homes, either in the UK or abroad, and that these households owned 651,000 properties.

\section{Figure 8 Households in England with a second home abroad: ${ }^{1}$ by location of second home, 2008/09}

England

Thousands

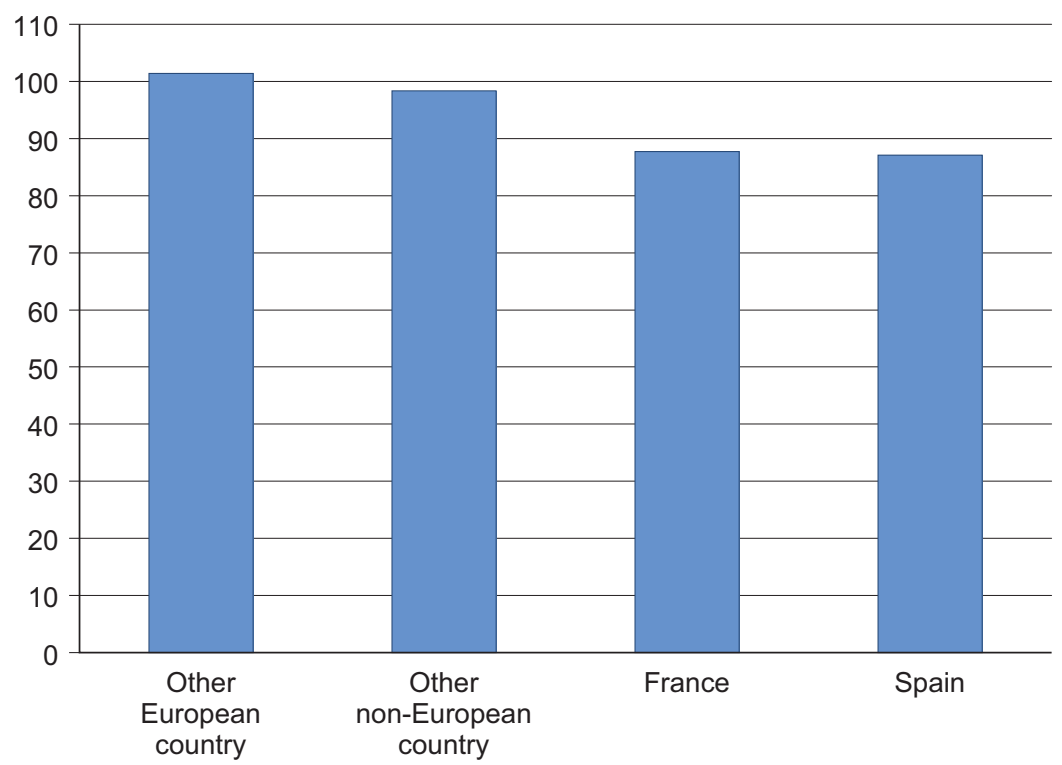

1 The definition of second homes excludes properties owned elsewhere that are let out as someone else's main residence.

Source: English Housing Survey, Department for Communities and Local Government (2009a)

The most often reported reason for a second home was its use as a holiday home or weekend residence (50 per cent of responding households). About 58 per cent or 375,000 properties used as second homes were located outside the UK, with nearly three-quarters located in Europe. The most popular locations were France $(88,000$ properties) and Spain $(87,000)$ (Figure 8). There were 101,000 properties throughout other European countries which were second homes for English households and around 98,000 in non-European countries (Department for Communities and Local Government, 2009a).

In 2008/09, 36.9 per cent of second homes by households resident in England were themselves located in England (240,000 properties). A further 36,000 (5.5 per cent) of second homes were in other parts of the UK (Department for Communities and Local Government, 2009a). 


\section{Table $5 \quad$ Domestic trips ${ }^{1}$ for holidays and visiting friends and relatives: by country}

United Kingdom

Millions

\begin{tabular}{|c|c|c|c|c|c|}
\hline & England & Northern Ireland & Scotland & Wales & United Kingdom \\
\hline \multicolumn{6}{|c|}{ Holidays } \\
\hline 2006 & 62.2 & 1.6 & 8.5 & 7.4 & 79.2 \\
\hline 2007 & 60.9 & 1.4 & 8.6 & 6.5 & 76.8 \\
\hline 2008 & 59.5 & 1.5 & 8.3 & 6.6 & 75.4 \\
\hline 2009 & 67.4 & 1.6 & 8.9 & 7.0 & 84.3 \\
\hline \multicolumn{6}{|c|}{$\begin{array}{l}\text { Visiting friends } \\
\text { and relatives }\end{array}$} \\
\hline 2006 & 20.3 & 0.4 & 1.9 & 1.1 & 23.7 \\
\hline 2007 & 21.2 & 0.4 & 1.9 & 1.3 & 24.7 \\
\hline 2008 & 18.0 & 0.3 & 1.6 & 0.8 & 20.6 \\
\hline 2009 & 18.1 & 0.4 & 1.4 & 1.0 & 20.8 \\
\hline
\end{tabular}

1 Trips refer to a visit with at least one night's stay.

Source: Visit England, Visit Scotland, Visit Wales, Northern Ireland Tourist Board (2010)

Domestic holidays within the UK, also known as 'staycations', are becoming more popular, according to statistics from the United Kingdom Tourism Survey ${ }^{\text {iv }}$. Figures show that between 2008 and 2009 domestic holidays in the UK increased by 12 per cent. However, between 2006 and 2008 domestic holidays were declining (Table 5). The increase between 2008 and 2009 could in part be due to the economic crisis which began in April 2008 with financial constraints meaning that holidays in the UK were preferred to those abroad. As with previous years the majority of domestic holiday trips in 2009 (79.9 per cent, 67 million trips) were taken in England, followed by Scotland with 10.5 per cent of holiday trips, then Wales with 8.3 per cent and Northern Ireland with 1.9 per cent.

The number of trips taken to visit friends and relatives in the UK were very similar in 2008 and 2009 at around 21 million. However, between 2007 and 2008 trips taken to visit friends and relatives decreased by 17 per cent (25 million trips in 2007 compared with 21 million trips in 2008).

The proportion of trips to visit friends and relatives in each UK country is very similar to the proportions for holidays in the UK. 
According to the Taking Part Survey, 70 per cent of adults aged 16 and over in England visited a heritage site in 2009/10, largely unchanged since 2005/06 (Department for Culture, Media and Sport, 2010).

\section{Figure 9 Proportion of adults ${ }^{1}$ who have visited a heritage site in the last year, 2009/10}

England

Percentages

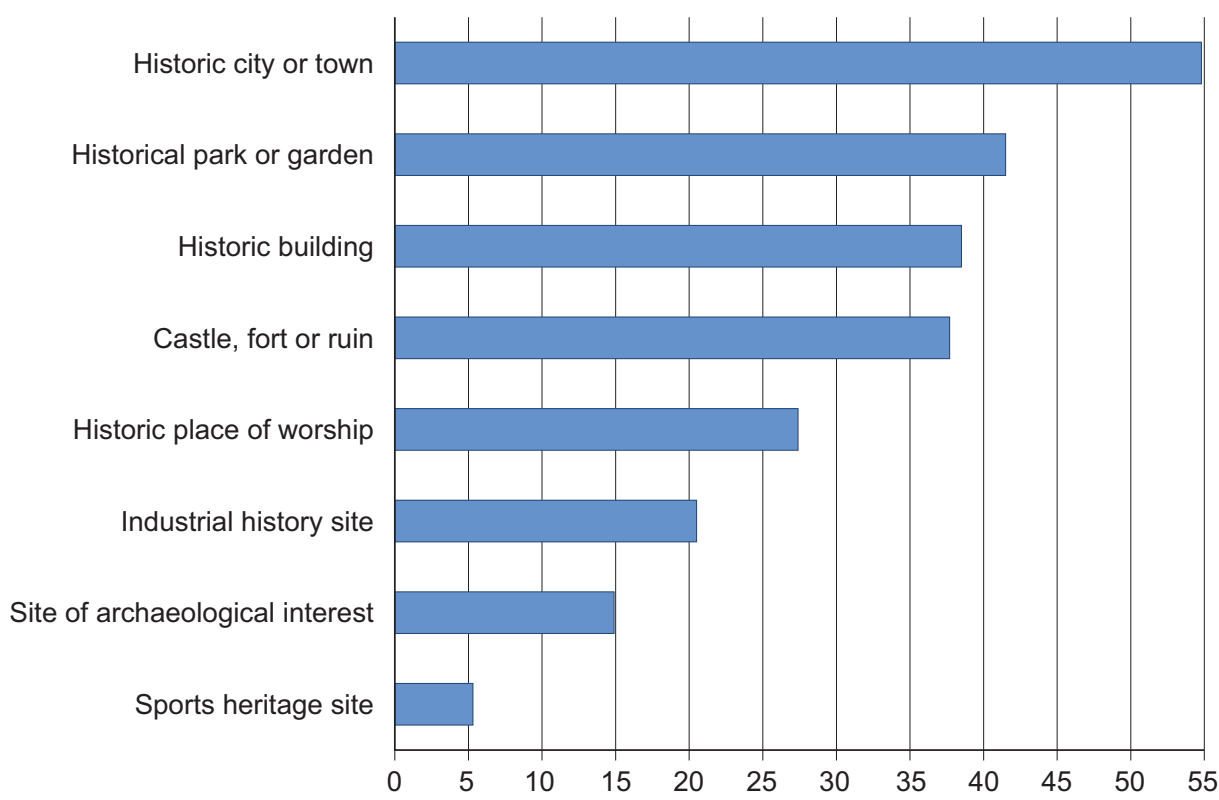

1 Adults aged 16 and over.

Source: Taking Part: The National Survey of Culture, Leisure and Sport, Department for Culture, Media and Sport (2010)

In 2009/10, as in previous years, the most popular type of heritage site visited was an historic city or town, with 55 per cent of adults who had visited a heritage site visiting these, followed by historic parks or gardens at 42 per cent and historic buildings at 39 per cent (Figure 9).

In 2009/10, 29.3 per cent of adults had visited an historic site three or four times in the past year and 26.1 per cent had been once or twice, while 12.5 per cent had been at least once a month and 2.5 per cent at least once a week. For people aged 75 and over, 51 per cent had visited one or more heritage sites in the last year. Those aged between 45 and 64 were the most likely to have visited a heritage site, with 77 per cent having done so in 2009/10. Men were marginally more likely to have visited a heritage site than women in 2009/10 (71 per cent compared with 68 per cent) (Department for Culture, Media and Sport, 2010).

According to a 2010 Eurobarometer Survey on attitudes towards tourism when deciding on a holiday destination, 32 per cent of EU citizens named the location's environment as the key consideration. This was followed by cultural heritage (25 per cent) and the options for entertainment (16 per cent). However, UK respondents placed cultural heritage as their top reason for choosing a holiday destination (30 per cent of respondents), followed by entertainment at 24 per cent and the environment at 15 per cent (Eurobarometer, 2010). 


\section{Sporting activities}

Many people engage in a wide variety of sport or physical activities in their free time. Individuals do this for many different reasons, ranging from improving health to having fun. The 2009/10 Taking Part Survey recorded that over half, 53 per cent, of adults aged 16 and over in England, had taken part in 30 minutes of active sport in the four weeks prior to being interviewed.

\section{Figure 10 Proportion of adults ${ }^{1}$ who have participated in active sport: by age, 2009/10}

England

Percentages

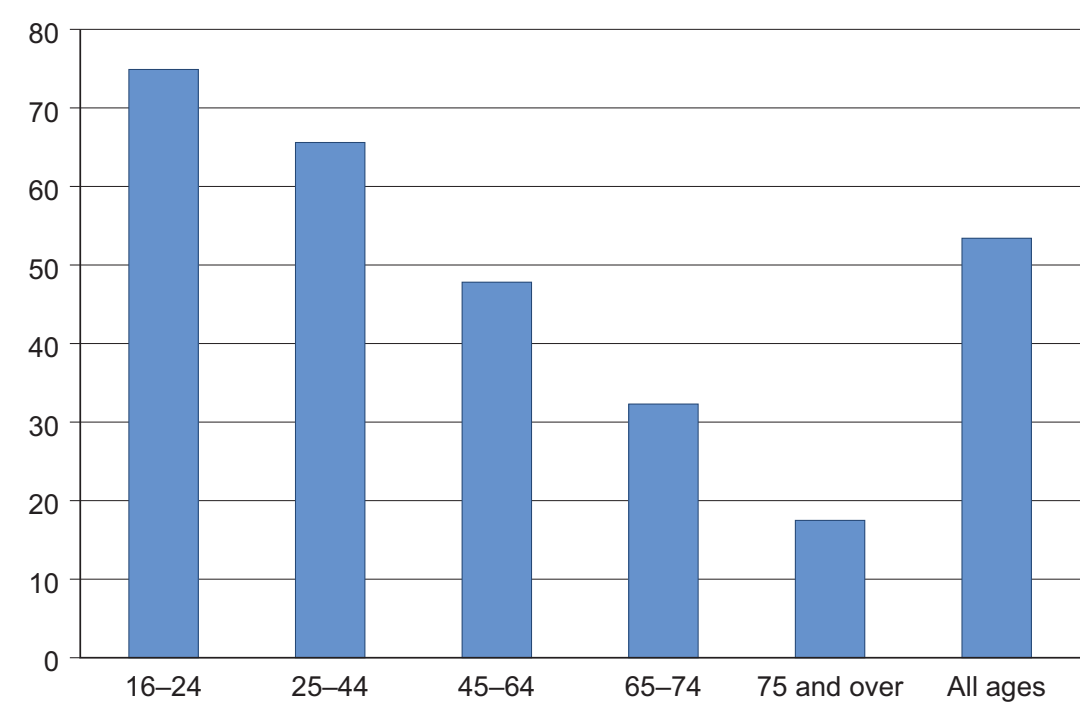

1 Adults aged 16 and over.

Source: Taking Part: The National Survey of Culture, Leisure and Sport, Department for Culture, Media and Sport (2010)

The proportion of those who did participate in active sport in the four weeks prior to interview decreased with age in 2009/10 (Figure 10). Of those aged 16 to 24, 75 per cent participated compared to 18 per cent of those aged 75 and over. Additionally, those who take part in active sport every day make up 6.7 per cent of the population, whereas those who take part on 21 to 27 days out of every 28 day period make up 3.3 per cent (Department for Culture, Media and Sport, 2010).

Not only were there differences in participation between the age groups, but there were also differences between men and women: 59 per cent of men had done active sport in the last four weeks prior to interview compared with 48 per cent of women. Among all adults doing sporting activities in the last four weeks, the top activities reported were health, fitness, gym or conditioning activities with 15.1 per cent and indoor swimming or diving with 14.7 per cent reporting having done this, followed by cycling at 10.5 per cent. Outdoor football and jogging, cross-county and road-running came next with around 6.7 per cent stating they did these (Department for Culture, Media and Sport, 2010). 
Although exercise and physical activity plays an important role in the lives of many, this is not the case for all and the reasons for not participating in forms of exercise vary from person to person. A Eurobarometer report conducted in October 2009 on sport and physical activity collected reasons preventing participation in sport. The most common reason was given as a lack of time ( 45 per cent of respondents on average across the EU) (Figure 11). A further 13 per cent of respondents on average said that disability or illness prevented them from taking part and 7 per cent did not like competitive activities. Only 3 per cent cited a lack of suitable facilities close to where they live and a further 3 per cent said they do not have friends with whom to do sports (Eurobarometer, 2009).

\section{Figure 11 Reasons preventing practicing sport more regularly, ${ }^{1} 2009$}

EU-27

Percentages

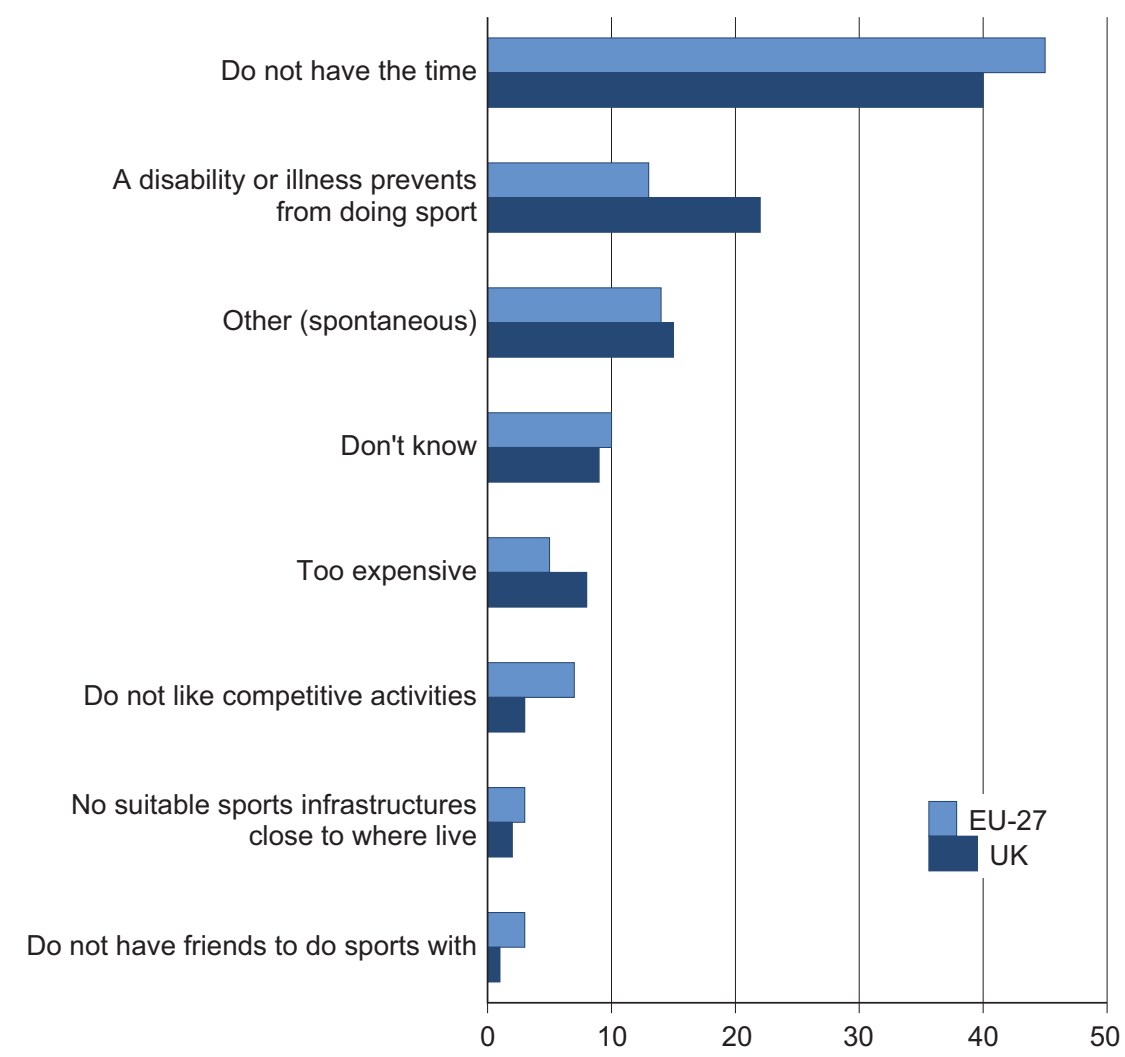

1 Respondents aged 15 and over were asked 'From the following reasons, what is currently preventing you the most from practicing sport more regularly?'.

Source: Eurobarometer (2009)

Not having the time to practice sport was the main reason provided by respondents from the UK, although the UK was below the EU-27 average with 40 per cent of UK respondents citing lack of time as a reason compared with the EU-27 average of 45 per cent.

However, the UK was above the EU-27 average for those citing a disability or illness preventing them from practicing sport. In fact, at 22 per cent, the UK's proportion was the highest across the EU-27. The UK was also above the EU-27 average for those stating that practicing sport was too expensive; with 8 per cent, the UK, along with Greece was the second highest country citing this, behind Portugal where 13 per cent cited cost as a reason. 
According to the same Eurobarometer report, 61 per cent of EU citizens who participated in sport or some other form of physical exercise did so to improve their health, while 41 per cent exercise to improve their fitness, 39 per cent to relax and 31 per cent to have fun (Eurobarometer, 2009).

The most common reason given by UK respondents was to improve health ( 65 per cent). The UK is also above the EU average for improving fitness (53 per cent) and to have fun ( 37 per cent). Thirty three per cent of UK respondents participated in sport or physical exercise to relax (Eurobarometer, 2009).

The Physical Education and Sport Strategy ${ }^{\vee}$ aims to get more young people in England taking part in high quality physical education (PE) and sport inside and outside of school. Results from the latest survey show that across all school age groups (years 1 to 13), over half (55 per cent) of all pupils participated in at least 3 hours of high quality PE and out of hours school sport in a typical week in 2009/10, (Figure 12). This is an increase of 5 percentage points from the 2008/09 survey (Department for Education, 2010).

\section{Figure 12 Pupils who participate in physical education and out of hour's school sport: ${ }^{1}$ by year group}

England

Percentages

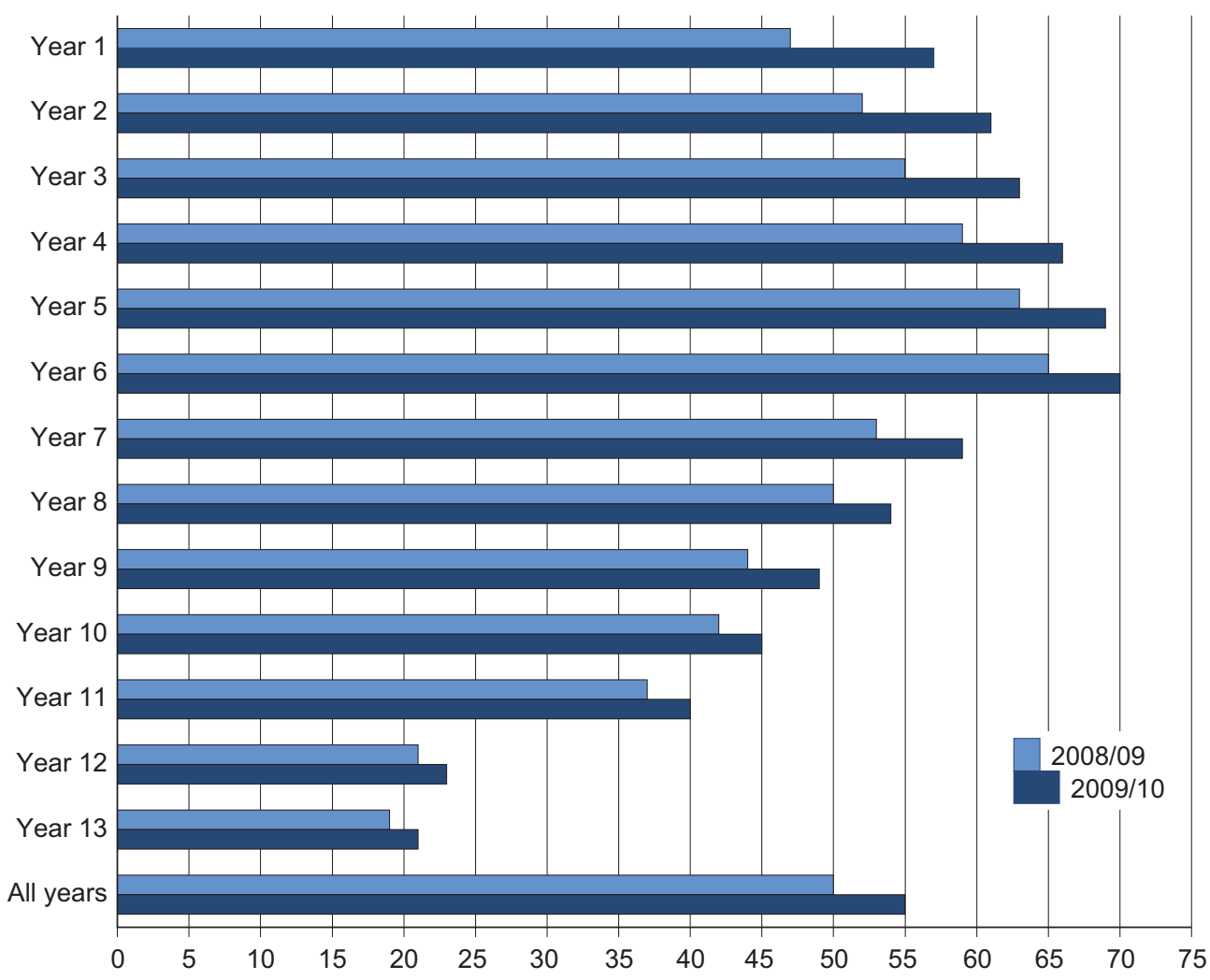

1 Based on pupils who participated in at least three hours of high quality PE and out of hours school sports in a typical week.

Source: Department for Education (2010)

Between 2008/09 and 2009/10 all year groups saw improvements in the percentage of pupils participating in at least 3 hours of high quality PE and out of school sports in a typical week. The 
largest improvements were for years 1 to 3 , while the smallest improvements were for years 12 and 13. Overall, year 1 saw the highest improvement from 47 per cent of pupils in 2008/09 to 57 per cent in 2009/10, followed by year 2 which increased from 52 per cent to 61 per cent and year 3 , from 55 per cent to 63 per cent. In comparison, years 12 and 13 both increased by only 2 percentage points from 21 per cent to 23 per cent and 19 per cent to 21 per cent respectively.

Overall, in 2009/10, participation levels were highest in years 5 and 6 , with year 5 reaching 69 per cent and year 6 recording the highest participation at 70 per cent. The survey also reported that boys were more likely than girls to participate in at least 3 hours of PE and out of school sport (58 per cent and 52 per cent respectively) (Department for Education, 2010). 


\section{Social and political participation}

The latest general election in May 2010 saw an increase in those who voted compared with the previous two elections but remained below levels seen in the 1997 election.

\section{Table $6 \quad$ General election turnout ${ }^{1}$}

\begin{tabular}{lllr} 
United Kingdom & & Percentages \\
\hline 1945 & 72.8 & Oct 1974 & 72.8 \\
1950 & 83.9 & 1979 & 76.0 \\
1951 & 82.6 & 1983 & 72.7 \\
1955 & 76.8 & 1987 & 75.3 \\
1959 & 78.7 & 1992 & 77.7 \\
1964 & 77.1 & 1997 & 71.4 \\
1966 & 75.8 & 2001 & 59.4 \\
1970 & 72.0 & 2005 & 61.4 \\
Feb 1974 & 78.8 & 2010 & 65.1 \\
\hline
\end{tabular}

1 Percentage of registered electorate who cast a valid vote.

Source: 1945-1997 Rallings and Thrasher (2007); 2001-2010 The Electoral Commission (2010)

Out of the 45.6 million people who were registered to vote in the 2010 general election, a total of 29.7 million valid votes were cast, an overall turnout rate of 65.1 per cent (Table 6). This was an increase of approximately 2.5 million voters compared with the 2005 UK general election, when turnout was 61.4 per cent. The 2005 and 2010 elections showed an upward trend in turnout rates since the 2001 general election when turnout fell to 59.4 per cent from 71.4 per cent in 1997. However, turnout figures are still relatively low. The percentage of the electorate who have turned out to vote was highest in 1950 at 83.9 per cent and was above 70.0 per cent between 1945 and 1997 (Electoral Commission, 2010) (Rallings, C. and Thrasher, M, 2007).

For the 2010 general election, turnout in England, Scotland and Wales increased compared with the 2005 general election. Turnout in England rose from 61.3 per cent in 2005 to 65.5 per cent in 2010, Wales increased from 62.6 per cent to 64.8 per cent, while Scotland was up from 60.8 per cent to 63.8 per cent. However, turnout in Northern Ireland decreased by 5.3 percentage points, from 62.9 per cent in 2005 to 57.6 per cent in 2010 (Electoral Commission, 2010).

Among those registered to vote in 2010 , turnout among postal voters was higher than for those who voted at polling stations, with 83 per cent of people who were sent a postal ballot pack voting, compared with 63 per cent of those who were required to vote at a polling station. While 15 per cent of eligible voters were issued with a postal vote in 2010 (an increase from 4 per cent in 2001), the majority of votes were cast in polling stations. In total more than 22 million votes, representing just over 82 per cent of all votes, were cast in around 40,000 polling stations across the UK (Electoral Commission, 2010). 
Research conducted by Ipsos MORI on behalf of the Electoral Commission for the 2010 UK general election found that the majority of the people in the UK were satisfied with the procedure for voting. In this survey, three-quarters (75 per cent) of respondents (including those who said they did not vote), were very or fairly satisfied with the procedure for voting, with only 13 per cent saying they were dissatisfied (Electoral Commission, 2010).

Among those who said they had voted, 80 per cent said they were satisfied with the voting process. Overall the satisfaction levels were highest among those aged 55 and over, of whom 83 per cent were satisfied compared with 67 per cent of 18 to 34-year-olds (Electoral Commission, 2010).

The 2009 British Social Attitudes survey ${ }^{\text {vi }}$ found that 57.6 per cent of people thought it was a person's duty to vote. A further 23.3 per cent stated that they only voted if they cared who won and 17.5 per cent thought it was not worth voting. There has been a steady increase in the proportion of people who believe that it is not worth voting, from 8.1 per cent in 1991 to 11.2 per cent in 2000 and 17.5 per cent in 2009 (British Social Attitudes, 2009).

The government's 'Big Society' aims to create a climate that empowers local people and communities, building a big society that will 'take power away from politicians and give it to people' (Num10, 2010). Volunteering, civil participation and charity work play a large role in this vision.

\section{Table $7 \quad$ Participation $^{1}$ in voluntary activities}

England

Percentages

\begin{tabular}{lccccr}
\hline & \multicolumn{2}{c}{ Formal volunteering $^{2}$} & & \multicolumn{2}{c}{ Informal volunteering $^{3}$} \\
\cline { 2 - 3 } & At least once a month At least once a year & & At least once a month At least once a year \\
\hline 2001 & 27 & 39 & 42 & 34 & 67 \\
2003 & 28 & 44 & 37 & 63 \\
2005 & 29 & 43 & 37 & 68 \\
$2007 / 08$ & 27 & 41 & 35 & 64 \\
$2008 / 09$ & 26 & 40 & 35 & 54 \\
$2009 / 10$ & 25 & & 29 & 62
\end{tabular}

1 Participation by adults aged 16 and over.

2 Formal volunteering: giving unpaid help through groups, clubs or organisations to benefit other people or the environment.

3 Informal volunteering: giving unpaid help as an individual to people who are not relatives.

Source: Citizenship Survey, Department for Communities and Local Government (2010)

The Citizenship Survey ${ }^{\text {vii }}$ collects information on both formal and informal volunteering. In England in 2009/10, 40 per cent of adults aged 16 and over volunteered formally at least once in the 12 months prior to interview, with 25 per cent having volunteered formally at least once a month (Table 7).

Levels of informal volunteering were higher than levels of formal volunteering, for both those who volunteered once a month and at least once a year, however both have shown decreases. In 
2009/10, 54 per cent of adults volunteered informally at least once in the 12 months prior to interview, a decrease from 62 per cent in the previous year, the largest decrease observed. An estimated 29 per cent volunteered informally at least once a month, a decrease from 35 per cent in the previous year.

There were some variations by age in the levels of volunteering. In 2009/10, those aged 75 years and over were less likely to participate in formal volunteering at least once a year (29 per cent) than any other age group. Those aged 75 years and over were also less likely to participate in informal volunteering at least once a year (40 per cent) than any other age group (Department for Communities and Local Government, 2010).

Although overall volunteering appears to be decreasing, according to data from Museums, Libraries and Archives (MLA) volunteering in public libraries in England, increased by 22 per cent between 2006/07 and 2008/09. In the museums, libraries and archives sector, 38,570 people volunteered in 2008/09, with over half of these, 20,805 volunteers, being in museums and galleries, a further 15,001 volunteering in libraries and 2,764 volunteers working in archives (Museums, Libraries \& Archives, 2010b).

Museums and galleries also received the highest number of volunteer hours per volunteer with an average of 265 volunteered hours of support per volunteer in 2008/09. Despite the lower numbers of volunteers within archives, this area had a higher number of average hours per volunteer at 74 hours, compared with libraries at 33 hours (Museums, Libraries \& Archives, 2010b).

A survey conducted by YouGov questioned adults in Wales about their motivation to take part in voluntary activities. It found that 64 per cent of those who volunteered stated they did so to help others. The next most common reason, given by 48 per cent of respondents, was that 'it gives me a sense of personal achievement/satisfaction'. This was followed by 'to promote a cause/campaign' at 34 per cent, to 'meet new people/make friends' at 27 per cent and 26 per cent stated that they volunteered to 'learn/develop new skills' and 'to have fun'. Only 14 per cent said that they volunteered to 'further my career' (YouGov, 2010c). 


\section{Figure 13 Participation ${ }^{1}$ in civic engagement}

\section{England}

Percentages

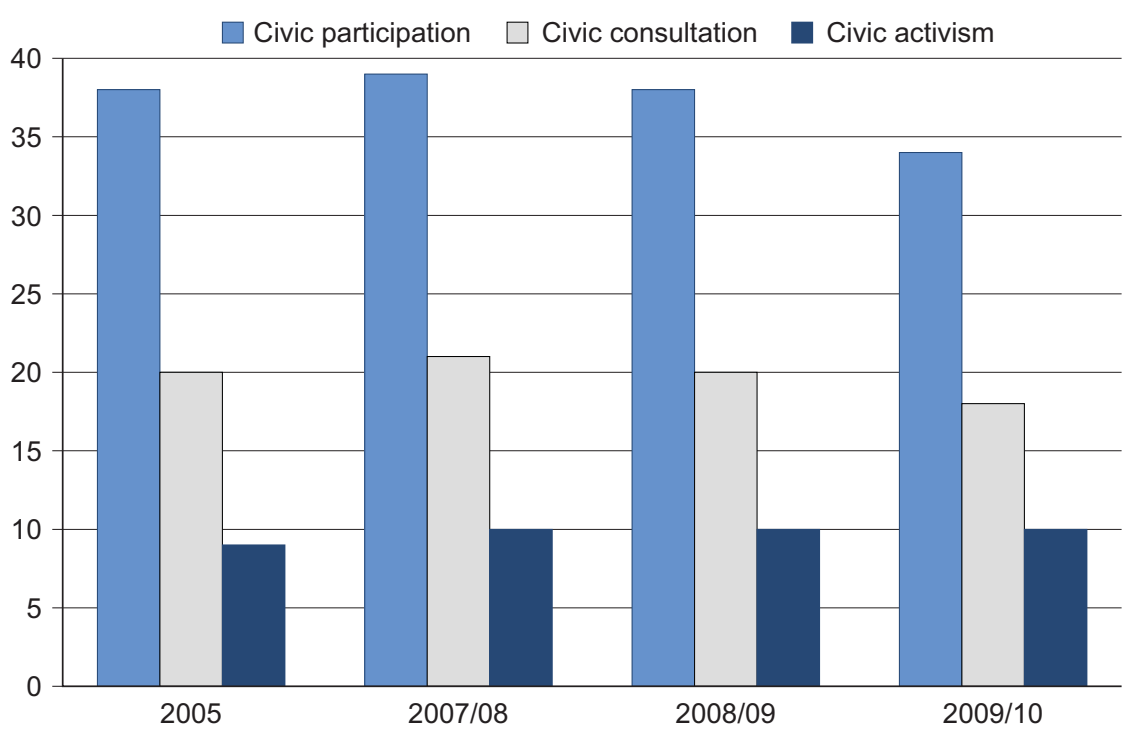

1 Participation of adults aged 16 and over at least once in the 12 months prior to interview.

Source: Citizenship Survey, Department for Communities and Local Government (2010)

Civil engagement is also reported on through the Citizenship Survey, which measures levels of participation in three broad strands: civic participation ${ }^{\text {viii }}$, civic consultation ${ }^{\mathrm{ix}}$ and civic activism ${ }^{\mathrm{x}}$ (Department for Communities and Local Government, 2010).

In 2009/10 in England, 10 per cent of adults aged 16 and over had participated in civic activism in the 12 months prior to interview, slightly higher than in 2005 (9 per cent) but the same level as in 2007/08 (Figure 13). The proportion of people engaged in some form of civic participation has been falling gradually, from 38 per cent in 2001 to 34 per cent in 2009/10. Participation in civil consultation has also fallen, with 18 per cent of people actively engaged in 2009/10 compared with 21 per cent in 2007/08 (Department for Communities and Local Government, 2010). 
According to a report from Charities Aid Foundation and National Council for Voluntary Organisations, over half of all adults aged 16 and over in the UK donated to charitable causes in 2009/10. In a typical month, 56 per cent donated (equivalent to 28.4 million adults), 2 percentage points higher than in 2008/09. The estimated total amount donated in 2009/10 was $£ 10.6$ billion, an increase of 3.9 per cent or around $£ 400$ million, after adjusting for inflation, compared with 2008/09 when $£ 10.2$ billion was donated. However donations have not returned to the pre recession record level of $£ 11.3$ billion recorded in 2007/08 (Charities Aid Foundation/National Council for Voluntary Organisations, 2010).

\section{Table $8 \quad$ Giving to charity: by age}

United Kingdom

Percentages

\begin{tabular}{lrrrr}
\hline & $\mathbf{2 0 0 6 / 0 7}$ & $\mathbf{2 0 0 7 / 0 8}$ & $\mathbf{2 0 0 8 / 0 9}$ & $\mathbf{2 0 0 9 / 1 0}$ \\
\hline $16-24$ & 42 & 42 & 38 & 39 \\
$25-44$ & 57 & 55 & 55 & 58 \\
$45-64$ & 60 & 63 & 57 & 63 \\
65 and over & 54 & 57 & 58 & 56 \\
All adults & 56 & 56 & 54 & 56 \\
\hline
\end{tabular}

1 For some years the percentages differ slightly from those shown in some previous reports, this is because the percentages for all years have been recalculated to be consistent with improvements in methods of weighting and syntax.

Source: Charities Aid Foundation and National Council for Voluntary Organisations (2010)

In 2009/10, as in previous years the likelihood of giving to charitable organisations was lower in the 16 to 24 age group than in the older age groups, the percentage of those in this age group, giving fell from 42 per cent in 2006/07 to 39 per cent in 2009/10. The largest increase in the proportion of people giving between 2008/09 and 2009/10 was by people aged 45 to 64 , up by 6 percentage points (Table 8). This age group had the highest proportion of people giving to charity in 2009/10, as in all previous years back to 2006/07, except 2008/09 when those aged 65 and over had the highest proportion of people giving to charity.

In 2009/10, as in previous years, women were more likely to donate than men; 61 per cent of women gave to charity compared with 52 per cent of men. In previous years, men who donated gave slightly more on average than women but in 2009/10 women and men gave similar amounts on average (£31). Donors were most likely to support medical research (32 per cent), children and young people ( 25 per cent) and hospitals (24 per cent). In 2009/10 overseas causes were also supported by 24 per cent of donors, higher than in previous years (Charities Aid Foundation/National Council for Voluntary Organisations, 2010).

In 2009/10 cash was still the most popular method of giving, with half of all donors (50 per cent) using this method compared with 29 per cent who gave by direct debit. Other methods included buying goods ( 25 per cent) and buying raffle tickets (20 per cent). Although cash was the most common method of giving, it did not account for the largest share of the value of donations. The total amount given by cheque or card was particularly high in 2009/10 and accounted for the largest share of the total amount donated, 29 per cent compared with 23 per cent in 2008/09. The 
total amount given using this method does fluctuate from year to year, while the total amount given by direct debit is more consistent, although the share of total donations accounted for by direct debits decreased slightly from 24 per cent in 2008/09 to 22 per cent in 2009/10. In 2009/10, 7 per cent of donors had made donations online, an increase of 3 percentage points from 4 per cent in 2008/09 (Charities Aid Foundation/National Council for Voluntary Organisations, 2010). 


\section{Religion}

The 2008/09 Race, Religion and Equalities Topic Report based on data from the Citizenship Survey, shows that 82 per cent of adults aged 16 and over in England and Wales reported having a religion in 2008/09, while 18 per cent reported having no religion. The largest proportion of those with a religious affiliation reported being Christian, with 72 per cent stating that this was their religion. The next most common religious groups reported were Muslims (4 per cent) and Hindus (2 per cent), while 1 per cent reported being Sikh and 1 per cent reported being Buddhist. A further 3 per cent of people responded 'other religion' (Department for Communities and Local Government, 2009b).

\section{Figure 14 Adults ${ }^{1}$ practicing a religion as a proportion of those having that religion, ${ }^{2} 2008 / 09$}

England \& Wales

Percentages

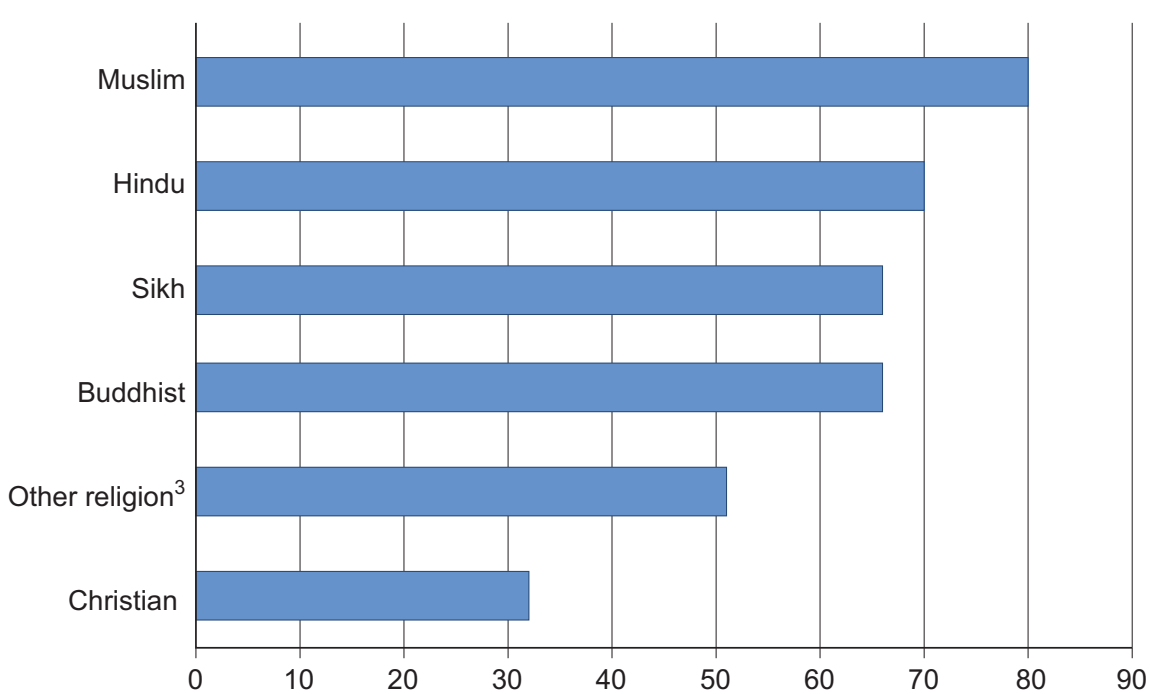

1 Figures based on adults aged 16 and over who reported having a religion.

2 Figures based on combined sample comprised of a core sample and an ethnic minority boost.

3 Jewish respondents included in 'other religion' due to small numbers.

Source: Citizenship Survey, Department for Communities and Local Government (2009b)

The proportion of those who had identified a religion and also said that they actively practised it varied according to the religion. Only 32 per cent of those who reported themselves as Christians actively practised their religion (Figure 14). In contrast, 80 per cent of Muslims actively practised their religion, the highest proportion of those with a religion who actively practiced. Two-thirds or more of Hindus, Sikhs and Buddhists actively practised their religion (70 per cent, 66 per cent and 66 per cent respectively). Among people in the 'other religion' category, 51 per cent said that they were actively practising.

Overall, women were more likely than men to say that they actively practised their religion, 42 per cent of women who reported a religion were actively practising compared with 31 per cent of men. People aged 50 and over were also more likely to actively practise their religion than those aged 16 to 29: 41 per cent and 29 per cent respectively (Department for Communities and Local Government, 2009b). 
The same report also stated that 94 per cent of people who said that they actively practised their religion felt that they could practise their religion freely in Britain. Additionally, in 2008/09, 52 per cent of people thought that there was more religious prejudice 'today' than there was five years ago, a decrease from 62 per cent in 2007/08 (Department for Communities and Local Government, 2009b).

\section{Figure 15 Influence of religion on day-to-day life, ${ }^{1} 2008 / 09$}

\section{England \& Wales}

Percentages

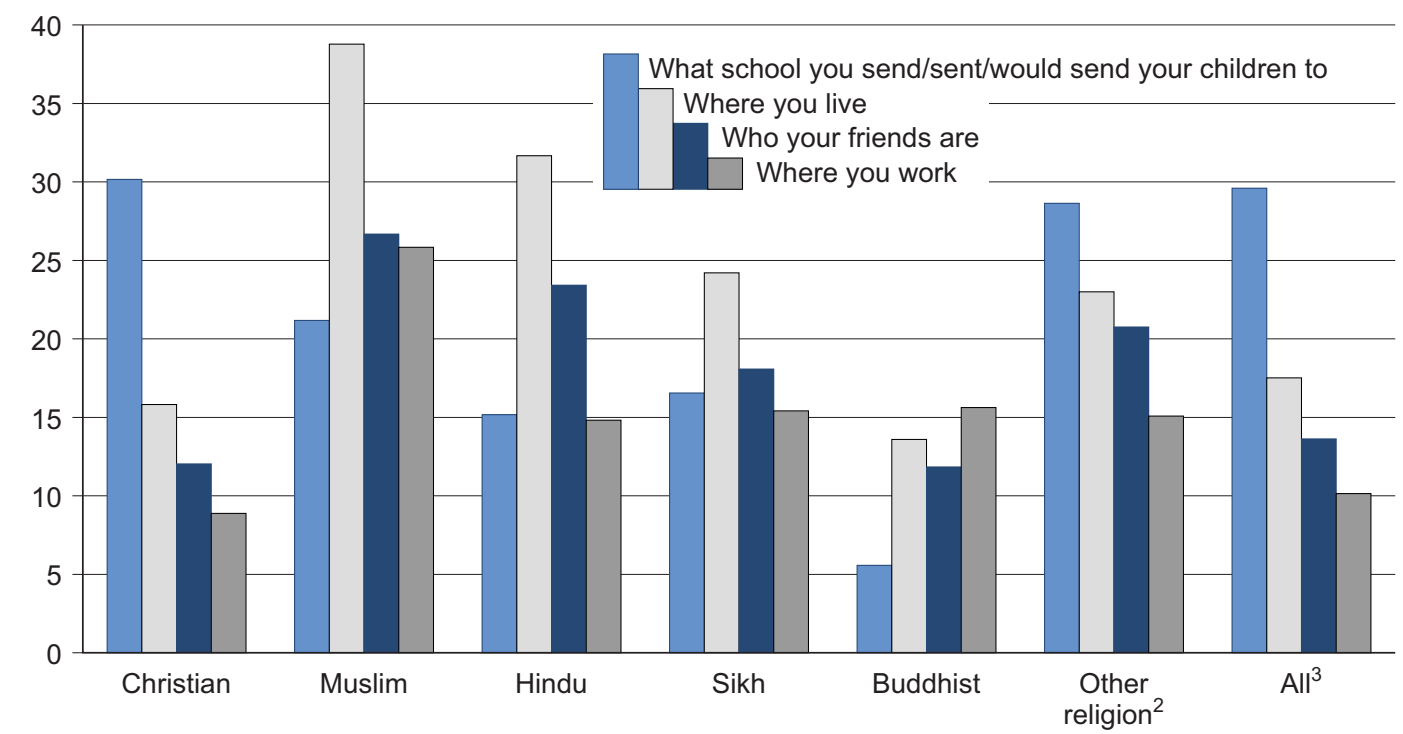

1 Excludes respondents with no religion, those with missing answers or religion data, and those that answered 'don't know' and 'not applicable'.

2 Jewish respondents included in 'other religion' due to a small numbers.

3 'All' category based on core sample. Other categories based on combined sample comprised of a core sample and an ethnic minority boost.

Source: Citizenship Survey, Department for Communities and Local Government (2009b)

In response to the same Survey, the majority of people said that their religion did not affect what school they send (or sent or would send) their children to, where they live, who their friends are or where they work. Thirty per cent of those with a stated religion said that religion influenced their choice of school, while 18 per cent of people who had a religion said that it did influence where they lived, 14 per cent said it influenced who their friends were and 10 per cent said it influenced where they worked (Figure 15).

Christian people were more likely than those of other religions (Muslim, Hindu, Sikh and Buddhist) to say that their religion influenced their choice of school: 30 per cent of Christians said this compared with 21 per cent of Muslims, 17 per cent of Sikhs, 15 per cent of Hindus, and 6 per cent of Buddhist respondents. However Christians were less likely than Muslims, Hindus, Sikhs or people in the 'other religion' category to say that their religion influenced where they live, where they work, and who their friends are. For example, only 16 per cent of Christians stated that their religion affected where they lived, compared with 39 per cent of Muslims, 32 per cent of Hindus, 24 per cent of Sikhs, and 23 per cent of people in the 'other religion' category (Department for Communities and Local Government, 2009b). 
A higher percentage of Muslims reported religion influencing where they worked (26 per cent) compared with 16 per cent of Buddhists; 15 per cent of Hindu, Sikh and people in the 'other religion' category; and 9 per cent of Christians (Department for Communities and Local Government, 2009b).

Men were more likely than women to say that their religion affected where they live (19 per cent of men compared with 16 per cent of women) and who their friends are (15 per cent compared with 12 per cent) (Department for Communities and Local Government, 2009b). 


\section{References}

British Social Attitudes (2009). Voting opinions. Available at:

www.britsocat.com/Body.aspx?control=Registration\&ReturnUrl=\%2fBodySecure.aspx\%3fcontrol\% $\underline{3 \mathrm{dBritSocAtC} \text { ContentsList\&control=BritSocAtContentsList }}$

Charities Aid Foundation/National Council for Voluntary Organisations (2010). UK Giving 2010.

Available at: www.ncvo-vol.org.uk/research/giving

Department for Communities and Local Government (2009a). English Housing Survey 2008-09 Household Report. Available at:

www.communities.gov.uk/publications/corporate/statistics/ehs200809householdreport

Department for Communities and Local Government (2009b). 2008-09 Citizenship Survey: Race, Religion and Equalities Topic Report. Available at:

www.communities.gov.uk/publications/corporate/statistics/citizenshipsurvey200809equality

Department for Communities and Local Government (2010). Citizenship Survey: 2009-10 (April 2009 - June 2010), England. Available at:

www.communities.gov.uk/communities/research/citizenshipsurvey/quaterlystatisticalreleases/

Department for Culture, Media and Sport (2010). Taking Part: The National Survey of Culture, Leisure and Sport Adult and Child Report 2009/10. Available at:

www.culture.gov.uk/publications/7386.aspx

Department for Education (2010). PE and Sport Survey 2009/10. Available at:

http://publications.education.gov.uk/default.aspx?PageFunction=productdetails\&PageMode=public ations\&Productld=DFE-RR032

Eurobarometer (2010). Survey on the attitudes of Europeans towards tourism. Available at: http://ec.europa.eu/public opinion/flash/fl 291 en.pdf

Eurobarometer (2009). Sport and Physical Activity. Available at:

http://ec.europa.eu/public opinion/archives/ebs/ebs 334 en.pdf

Electoral Commission (2010). Report on the administration of the 2010 UK general election. Available at:

www.electoralcommission.org.uk/publications-and-research/election-

reports?query=\&meta $s$ phrase $=U K+$ Parliamentary+election\&sort=relevancy\&daat=on

Entertainment Retailers Association (2010). UK and Ireland's statistics. Available at: www.eraltd.org/content/stats.asp

Museums, Libraries \& Archives (2010a). Research Briefing 9: Trends from the CIPFA Public Library Service Statistics 2004/05 to 2008/09. Available at:

http://research.mla.gov.uk/evidence/view-publication.php?dm=nrm\&pubid=1118 
Museums, Libraries \& Archives (2010b). Volunteering in the mla sector: a discussion. Available at: http://research.mla.gov.uk/evidence/view-publication.php?dm=nrm\&pubid=1122

National Literacy Trust (2010). Available at:

http://www.literacytrust.org.uk/

National Readership Survey (2010). National Readership estimates. Available at: www.nrs.co.uk/toplinereadership.html

Number 10 (2010). Government launches ‘Big Society' Programme. Available at: http://www.number10.gov.uk/news/topstorynews/2010/05/big-society-50248

Ofcom (2010). Communications Market Report. Available at: http://stakeholders.ofcom.org.uk/market-data-research/market-data/communications-marketreports/cmr10/uk/

Office for National Statistics (2010). Travel Trends 2009. Available at: www.statistics.gov.uk/statbase/Product.asp?vlnk=1391

Public Lending Right (2009), 2008-09 Loans of books by category. Available at: www.plr.uk.com/mediaCentre/loansByCategory/loansByCategory.htm

Publishers Association (2009). PA statistics yearbook 2009. Available at: www.publishers.org.uk/index.php?option=com content \&view=category\&layout=blog\&id=154\&ltemi $\underline{\mathrm{d}=1295}$

Radio Joint Audience Research Limited (2010). RAJAR Data Release - Quarter 3, 2010. Available at: www.rajar.co.uk/content.php?page=news

Rallings, C. and Thrasher, M. (2007). British Electoral Facts 1832-2006. Ashgate Publishing Limited: Great Britain

UK Film Council (2010). Statisitcal Yearbook 2010. Available at: http://sy10.ukfilmcouncil.ry.com/Downloads.asp

Visit England, Visit Scotland, Visit Wales, Northern Ireland Tourist Board (2010). The UK Tourist 2009 Report. Available at:

www.visitbritain.org/insightsandstatistics/domesticvisitorstatistics/index.aspx

YouGov (2010a). Cinema going habits. Available at:

http://today.yougov.co.uk/pdfarchives/cinema-going-habits

YouGov (2010b). Newspapers and online content. Available at: http://today.yougov.co.uk/pdfarchives/newspapers-online-content

YouGov (2010c) Volunteering in Wales. Available at:

http://today.yougov.co.uk/pdfarchives/volunteering-wales 


\section{Notes}

i The Taking Part Survey is commissioned by the Department for Culture, Media and Sport in partnership with four of its Non Departmental Public Bodies (Arts Council England, English Heritage, Sport England and the Museums, Libraries and Archives Council).

ii www.statistics.gov.uk/cci/article.asp?ID=2604

iii The English Housing Survey is conducted by the Department for Communities and Local Government.

iv United Kingdom Tourism Survey is jointly funded and managed by Visit England, Visit Scotland, Visit Wales and the Northern Ireland Tourist Board.

${ }^{\vee}$ The Physical Education and Sport Strategy is run by the Department for Education.

${ }^{v i}$ The British Social Attitudes survey is conducted by the National Centre for Social Research.

vii The Citizenship Survey is conducted by the Department for Communities and Local Government.

viii Civic participation covers wider forms of engagement in democratic processes, such as contacting an elected representative, taking part in a public demonstration or protest, or signing a petition.

${ }^{\text {ix }}$ Civic consultation refers to active engagement in consultation about local services or issues through activities such as attending a consultation group or completing a questionnaire about these services.

${ }^{x}$ Civic activism refers to involvement either in direct decision-making about local services or issues, or in the actual provision of these services by taking on a role such as a local councillor, school governor or magistrate. 